\title{
MODERN MODEL OF EDUCATION AND TRAINING CENTER PREPARATION OF EXPERTS IN THE FIELD OF CHEMICAL, BIOLOGICAL, RADIATION AND NUCLEAR SAFETY
}

\author{
(Results of the first Chemical Safety Training under Project 57: \\ Strengthening Crime Scene Forensics Capabilities \\ in Investigating CBRN Incidents. Ukraine, Kyiv, July 2019)
}

\author{
S. Berezhnov1, G. Petrashenko', N. Kurdil', M. Zinovieva1', D. Fed², V. Raks³, \\ N. Zavialova ${ }^{4}$, L. Ustinova ${ }^{5}$, V. Korobka ${ }^{6}$, R. Shvets ${ }^{6}$ \\ 'L.I. Medved's Research Center of Preventive Toxicology, Food and Chemical Safety, \\ Ministry of Health, Ukraine (State Enterprise), Kyiv, Ukraine \\ IInternational Center for the Prevention of the Effects of CBRN Threats, Kyiv, Ukraine \\ ${ }^{3}$ Taras Shevchenko National University, Kyiv, Department of Analytical Chemistry, Kyiv, Ukraine \\ ${ }^{4}$ The State Scientific Research Forensic Center of the Ministry of Internal Affairs of Ukraine, \\ Kyiv, Ukraine \\ ${ }^{5}$ Ukrainian Military Medical Academy, Department of Military Toxicology, \\ Radiology and Medical Protection, Kyiv, Ukraine \\ ${ }^{6} P E$ «Sparing-Vist Center», Kyiv, Ukraine
}

\begin{abstract}
Minimizing the effects of chemical, biological, radiation and nuclear (CBRN) incidents requires the simultaneous efforts of different specialists not only within one state, so recently international projects have been chosen for the purpose of developing and implementing not only national measures to minimize CBRN threats, but also coordination at the international level.

The Aim of the Research. Substantiation of the relevance of a permanent international training center organization for the training of specialists in the field of CBRN security (direction - chemical security) for the needs of the power and special structures of Ukraine. Methods. Results of the instruction and trainings conducted within the framework of the project on the establishment of a network of training centers for minimizing the risks related to the CBRN threats in the countries of the region of Southeast and Eastern Europe, held on the basis of State Enterprise "Research Centre of Preventive Toxicology, Food and Chemical Safety named after L. I. Medved", Ministry of Healthcare of Ukraine” (Science Center) in July 2019.

Results and Discussion. Project 57: Strengthening the crime scene forensics capabilities in investigating CBRN incidents in the South East and Eastern Europe Centers of Excellence Region (Ref: Europe Aid / IFS / 2016/374993) came into action in 2019.

The objective of Project 57 is to introduce a system of trainings on the investigation of CBRN incidents and the gradual formation of relationships between forensic experts and organizations with experience in the field of CBRN materials at the national level. Successful fulfillment of the tasks of investigating CBRN incidents requires constant professional improvement of specialists in various fields and development of the system of communication and interaction at the interdisciplinary level.

Project 57 from Ukraine involved Ukrainian experts instructed and trained in EU countries as national forensic trainers in crime scene investigations. These candidates, after conducting the relevant exercises, were involved in conducting trainings on raising the level of knowledge of law enforcement officers of Ukraine. In July 2019, a team-based training (July 5) and national exercises (July 22-25) were held under Project 57 at the Science Center.

Law enforcement experts from Ukraine and Moldova participated in the team and staff training. Exercises were performed in groups, and the results of the work were demonstrated and discussed via Skype conference mode.

National exercises were conducted in the form of practical exercises in a specially prepared territory of the Science Center. The participants of the training worked with imitation material evidence in protective suits using technical means in real-time situations.

In addition to the acquisition of practical skills, there was an exchange of knowledge and experience between the various agencies involved in the field of chemical threat. The participants gained experience that will help to improve management skills and improve coordination and communication between the actors involved in the response to the CBRN incidents.

Conclusions. The conducted trainings proved the necessity of introducing a system of continuous professional instruction and advanced training of the staff of special and security structures of Ukraine involved in the investigation of CBRN incidents.
\end{abstract}

Key Words: chemical, biological, radiation and nuclear safety, continuous professional development. 
Introduction. The risks posed by chemical, biological, radiation and nuclear (CBRN) security now deserve the most attention of the world community. International CSRB security projects combine the efforts of scientists, industry, law enforcement and special government agencies to develop and implement the risks of national CBRN threats and to coordinate internationally.

The countries of the former Soviet Union (Ukraine, Moldova, Georgia, Armenia, Azerbaijan, etc.) have been actively involved in the recent years in resolving issues related to the Security Council, not only the formation of national expert networks in these countries, but also the development of already existing international experience and methodology of continuous qualification improvement of such specialists and formation of skills for their effective professional communication.

The International Center for the Prevention of the Effects of Radiation, Chemical, Biological and Nuclear Threats (Director Fed D.V.) is a non-governmental national expert partner in the framework of Project 57 [1].

Project 57: Strengthening crime scene forensics capabilities in investigating CBRN incidents in the South East and Eastern Europe Centers of Excellence Region (Ref: Europe Aid/ IFS/2016/374993)) [2].

The implementation of Project 57 is carried out jointly with the Consortium of the Belgian and Netherlands public institutions (hereinafter referred to as the Consortium). Project 57 began operations in 2019 to enhance existing forensic expertise in investigating CBRN incidents.

Objective of Project 57 is to introduce a system of trainings on CBRN incident investigations and progressively build relationships between forensic experts and organizations with experience in the field of CBRN materials at national level. Such activities require continuous professional improvement of specialists in various fields and development of the system of communication and interaction at the interdisciplinary level.

The Aim of the Research. Substantiation of the organization relevance of a permanent international training center for the specialists training in the field of CBRN security (direction - chemical security) for the needs of the power and special structures of Ukraine.
Methods and Materials. Results of the instruction and trainings conducted within the framework of the project on the establishment of a network of training centers for minimizing the risks related to the CBRN threats in the countries of the region of Southeast and Eastern Europe, held on the basis of State Enterprise "Research Centre of Preventive Toxicology, Food and Chemical Safety named after L. I. Medved", Ministry of Healthcare of Ukraine, Kyiv, Ukraine" (Science Center) in July 2019.

Results and Discussion. Within the framework of Project 57, Ukrainian experts from the State Expertise of the State Expert Forensic Center (Expert Service of the Ministry of Internal Affairs of Ukraine) have been involved [3], who have been instructed and trained as national trainers for forensic investigations at crime scenes, investigating the materials related to CBRN. These candidates, after appropriate training in EU countries, were involved in training for raising the level of knowledge of law enforcement officers of Ukraine, for which Project 57 conducted the following activities: team and staff training - July 5 and national training (educational) - July 22-25 year.

Specialists from Ukraine were included as experts-evaluators: Department of Analytical Chemistry of Taras Shevchenko National University of Kyiv (Ph.D., associate professor Raks V.A.) and Science Center (Ph.D. Kurdil N.V.). The experts from the Consortium (Belgium, the Netherlands) acted as observers.

The team-staff training was held in the form of an online training and a Skype conference. The online training was conducted in the form of a discussion where all participants from each country were gathered in one room. Participants were divided into roles (players, controllers/evaluators, observers) to accomplish tasks in different directions (decision making, evaluation, public communications, working with the media, policy definition and response, etc.). According to the given scenario, all participants participated in the discussion of an imaginary emergency (largescale chlorine emission accident), conducted under the general guidance of the lead moderator and carried out through electronic messaging.

The main objective of the event was to improve the professional skills of forensic experts in response to criminal events related 
to the release of hazardous chemicals at the crime scene.

The main objectives of the online training were: to get acquainted with colleagues from another country involved in the investigation of a crime (transboundary movement of a dangerous chemical), including roles and responsibilities at both national and international levels; exchange of knowledge and experience between different countries; improving managerial skills; improving coordination and communication between the parties involved in the response; learning in real-time situations; strengthening teamwork; identify weaknesses in existing emergency response procedures; improvement of legal regulation mechanisms, organization, plans and procedures; strengthening partnerships between national and international levels of emergency management.

Practical exercises included the following tasks for the participants of the Internet training: collection of information about the event; establishing communication with third parties regarding safety assessment and decontamination (neutralization) of personnel and materials; assessing the risk associated with the incident and determining the required level of personal protective equipment (PPE); communication with the investigation authorities on the results of the investigation and discussion of the next steps; the development of an action plan that involved the collection of evidence, an assessment of the nature of the incident, the results of intelligence and first-party information, the designation of the investigating authority (for example, to identify the truck hijackers and possible related persons).

Particular attention was paid to developing a plan for sorting the evidence collected to address the following questions: what laboratory studies should be conducted and which laboratories should be involved; what is the procedure for deactivating evidence (if applicable); how to pack evidence and decontaminate packaging; how to transport material to research toxicology laboratories and reference centers in accordance with national rules.

The exercises were performed in groups, the results of the work were demonstrated via Skype.

The next action under Project 57 was to conduct a national training, which took place on July 22-25, 2019 at the Science Center and was held in the form of plenary reports, discus-

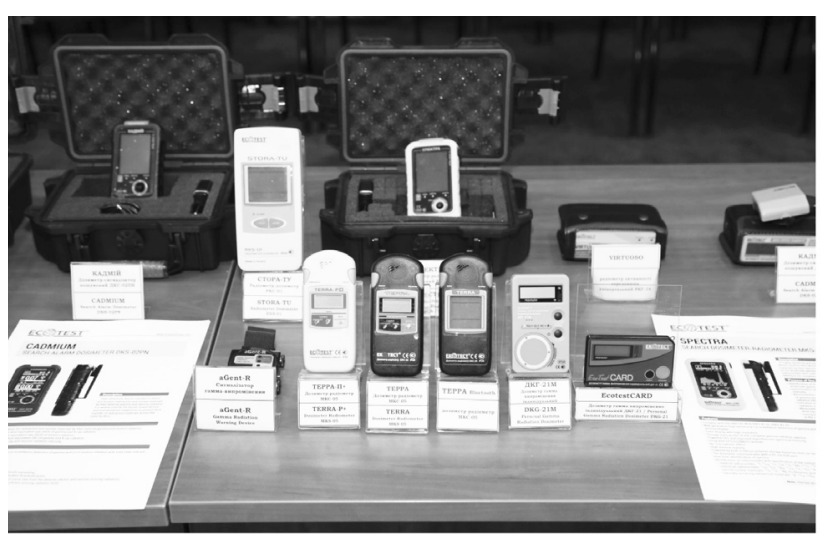

Fig. 1. Means of CBRN of Intelligence of Private Enterprise Scientific and Production Private Enterprise "Sparring-Vist Center" (Ukraine).

sions and practical exercises. Participants in the national training were representatives of law enforcement and special structures (primarily experts and forensic experts working in the field of human security) in Ukraine. In total, 25 managers and specialists, assistants and appraisers participated in the training.

The main objective of the event was to raise awareness and acquire theoretical knowledge in the field of contemporary CBRN threats and improve the practical skills of specialists in various fields, including forensic experts, in response to criminal events related to the release of hazardous chemical substances.

The first phase of the national training took the form of a seminar on the following topics:

- The Role and Place of State Enterprise "Research Centre of Preventive Toxicology, Food and Chemical Safety named after L. I. Medved", Ministry of Healthcare of Ukraine, Kyiv"in the system of chemical safety and security in Ukraine;

- International legislation in the field of CBRN terrorism;

- Procedure of actions of police bodies (units) in case of detection of radioactive, chemical and nuclear materials or receiving information about violations of the rules or illegal handling of them;

- Forensic expert support of crime detection;

- Modern chemical analytical centers are an instrument of the national security system;

- Modern methods of nuclear forensics;

- Biosafety: risk assessment, detection, counteraction and prevention of biological threats;

- Priority ways for the development of the CSRC protection and development tools 


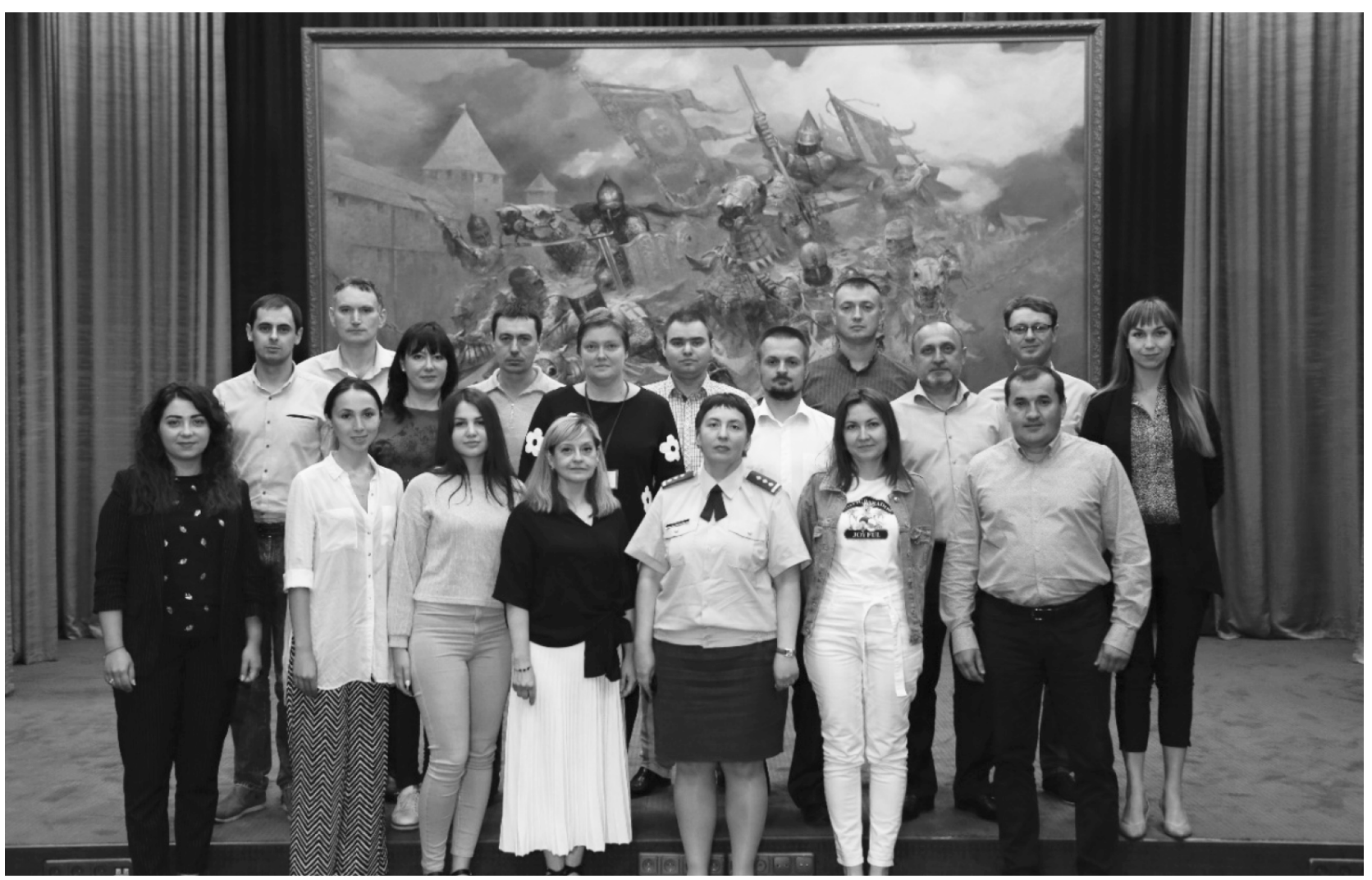

Fig. 2. Project 57 trainers and consultants: Enhancing the capacity of forensics to investigate incidents involving radiation, chemical, biological, and nuclear (CBRN) materials. Ukraine, Kyiv, July 2019

for the private enterprise «Scientific and Production Private Enterprise «SparingVist Center»;

- Analysis of existing samples of personal protective equipment and indication in the Armed Forces of Ukraine;

- Perspectives of employee training of the force and special structures of Ukraine on chemical and radiation safety, protection against factors of mass destruction at the Department of Military Toxicology, Radiology and Medical Protection of the Ukrainian Military Medical Academy.

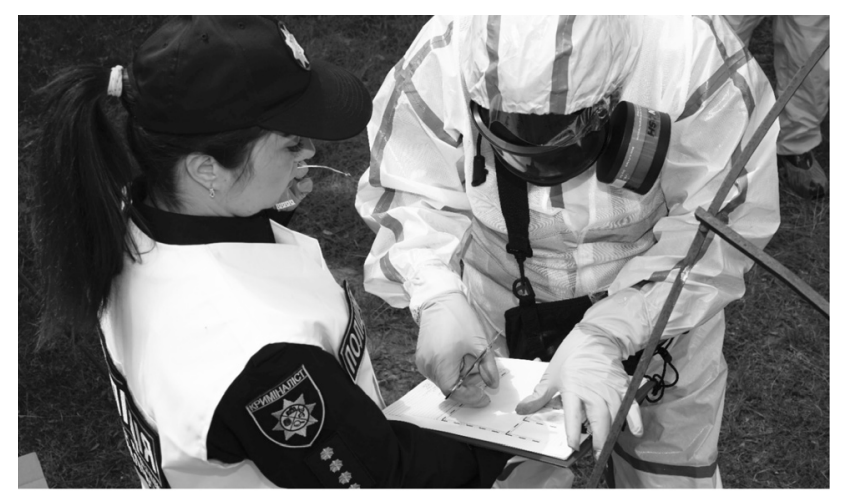

Fig. 3. Practical exercises (work of forensic expert with samples in protective suit) during the national training under Project 57. Ukraine, Kyiv, July 24, 2019
The main objectives of the first phase of the training were: to get acquainted with the basics of international legislation in the field of CBRN threats; acquaintance with the action procedure of police bodies (units) in case of CBRN incidents' occurrence or receiving information about violations of the rules or illegal handling of them; getting acquainted with the modern standards of forensic expert support of crime detection and the work of chemical-analytical centers of EU countries and individual countries of the world; acquain-

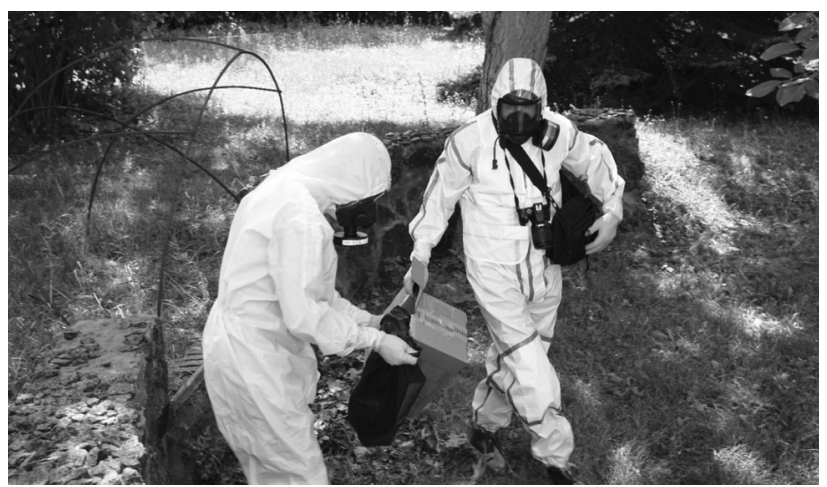

Fig. 4. Performing practical exercises (site review and sampling) during national training under Project 57. Ukraine, Kyiv, July24, 2019 
tance with the methods of modern nuclear forensics. Within the framework of the training-workshop, an exhibition and demonstration of samples of the CBRN protection and intelligence of production of the private enterprise Scientific and Production Private Enterprise "Sparing-Vist Center" (Ukraine) were held [4].

The second phase of the national training involved the implementation of practical exercises in the open field. For the practical part of the training seminar, the territory in the park zone located in the territory of the Science Center was selected. At the disposal of the training participants were imitation physical evidence, PPE, equipment for photo and video fixation, professional technical equipment. Practical exercises involved dealing with material evidence. Video and photography of the main stages of the training were conducted.

The main tasks of the second stage of the training are: to acquire practical working skills in the field of CBRN incidents; improving managerial skills; learning in real-time situations; improving the quality of teamwork; identifying weaknesses in existing procedures for responding to and cooperation between security and special forces structures in the face of the CBRN threat. After the activities were completed, the work was evaluated and the results were summarized.

Overall, the objectives of the activities have been achieved, which confirm the obtained results:

- a direct acquaintance was conducted with colleagues from various government forces and special structures involved in the response and investigation of the crime related to the CBRN materials, including roles and responsibilities at both national and regional levels;

- there was an exchange of knowledge and experience within and between different agencies, as subjects of interaction in terms of the CBRN threats;

- experience was gained that will enhance management skills and improve coordination and communication between the individuals involved in responding to the $\mathrm{CBRN}$ incidents;

- training of the staff of the forensic expert service was held in real-time situations;

- the quality of teamwork has improved;

- deficiencies in existing emergency response procedures related to $\mathrm{CBRN}$ materials have been identified;

- information was obtained on improving regulatory mechanisms, organization, plans and procedures;

- information on strengthening partnerships between local and national actors was received;

- there was an exchange of information and experience between the participants, the establishment of personal contacts.

Conclusions. The results of the exercises, which are conducted in conditions close to the real ones, clearly show all the positive and negative aspects of the teams of specialists and confirm the need to introduce a system of continuous professional instruction and training of employees of special and security structures of Ukraine involved in the investigation of the CBRN incidents.

\section{REFERENCES}

1. International Center for the Prevention of the Effects of CBRN Threats. [Website]. URL:http://cbrn.center/. (date of appeal: 25.01.2020).

2. EU Chemical, Biological, Radiological and Nuclear Risk Mitigation Centres of Excellence (CoE).[Website]. URL: https://ec.europa.eu/jrc/en/research-topic/chemical-biological-radiological-and-nuclear-hazards/cbrn-risk-mitigation-centres-of-excellence. (date of appeal: 25.01.2020).
3. Ministry of Internal Affairs Expert Service of Ukraine. State Scientific-Forensic Expert Center. [Website]. URL: https://dndekc.mvs.gov.ua/. (date of appeal: 25.01.2020).

4. Privateenterprise «Scientific and Production Private Enterprise «Sparing-VistCenter» (PE «SPPE «SparingVistCenter»). Official website. Electronic resource. URL:http:www.ecotestgroup.com. (date of appeal: 25.01.2020). 


\section{СУЧАСНА МОДЕЛЬ НАВЧАЛЬНО-ТРЕНІНГОВОГО ЦЕНТРУ 3 ПІДГОТОВКИ ЕКСПЕРТІВ У СФЕРІ ХІМІЧНОЇ, БІОЛОГІЧНОЇ, РАДІАЦІЙНОЇ ТА ЯДЕРНОЇ БЕЗПЕКИ}

(Результати першого тренінгу з хімічної безпеки в рамках Проекту 57: Посилення існуючих експертно-криміналістичних можливостей при розслідуванні ХБРЯ інцидентів. Україна, Київ, липень 2019 р.)

С.П. Бережнов ${ }^{1}$, Г.І. Петрашенко ${ }^{1}$, Н.В. Курділь ${ }^{1}$, М.Л. Зінов єва ${ }^{1}$, Д.В. Федь ${ }^{2}$, В.А. Ракс ${ }^{3}$, Н.Г. Зав ялова ${ }^{4}$, Л.А. Устінова ${ }^{5}$, В.П. Коробка ${ }^{6}$, Р.М. Швець ${ }^{6}$

${ }^{1}$ ДП «Науковий центр превентивної токсикології, харчової та хімічної безпеки імені академіка Л.І. Медведя

Міністерства охорони здоров'я України», м. Київ, Україна

${ }^{2}$ Міжнародний дослідний центр запобігання наслідків ХБРЯ загроз, м. Київ, Україна

${ }^{3}$ Киівський національний університет імені Тараса Шевиенка, кафедра аналітичної хімії, м. Київ, Україна

${ }^{4}$ Держкавний науково-дослідний експертно-криміналістичний иентр МВС України, м. Київ, Україна

${ }^{5}$ Украӥнська військово-медична академія, кафедра військової токсикології, радіології та медичного захисту, м. Київ, Україна

${ }^{6}$ ПП «Спаринг-Віст Центр», м. Киів, Україна

PEЗЮМЕ. Мінімізація наслідків інцидентів, пов'язаних з хімічною, біологічною, радіаційною та ядерною (РХБЯ) небезпекою, потребує одночасних зусиль різних спеціалістів не лише в межах однієї держави, тому останнім часом міжнародні проекти обирають за мету розробку і впровадження не лише національних заходів з мінімізаиії РХБЯ загроз, а й координацію дій на міжннародному рівні.

Мета. Обгрунтування актуальності організації постійно діючого міжкнародного тренінг-центру з підготовки спеціалістів у сфері РХБЯ безпеки (напрям - хімічна безпека) для потреб силових і спеціальних структур України.

Матеріали і методи. Результати проведених навчань і тренінгів у рамках проекту, присвяченого створенню мережі тренінг-центрів з мінімізації ризиків, пов'язаних з РХБЯ загрозами в країнах регіону Південно-Східної і Східної Європи, що відбулися на базі ДП «Науковий центр превентивної токсикології, харчової та хімічної безпеки імені академіка Л.І. Медведя МОЗ України» (Науковий центр) в липні 2019 р.

Результати і обговорення. Проект 57 - «Посилення існуючих експертно-криміналістичних можливостей при розслідуванні РХБЯ інцидентів» (англ. Project 57: Strengthening crime scene forensics capabilities in investigating CBRN incidents in the South East and Eastern Europe Centers of Excellence Region (Ref: Europe Aid/ IFS/2016/374993) почав діяльність у 2019 роиі.

Завдання Проекту 57 - запровадження системи тренінгів з розслідування РХБЯ інцидентів та поступове формування взаємозв'язків мізк експертами-криміналістами і організаціями, що мають досвід роботи у сфері РХБЯ матеріалів на національному рівні. Успішне виконання завдань з розслідування РХБЯ інцидентів потребує постійного професійного вдосконалення спеціалістів різних галузей і розвитку системи комунікації та взаємодії на міждисииплінарному рівні.

У рамках реалізації Проекту 57 від України було залучено українських експертів, які пройшли навчання та підготовку в країнах $Є С$ у якості національних інструкторів з судово-криміналістичних експертиз на місці злочинів при розслідуванні інцидентів, пов'язаних з РХБЯ матеріалами. Зазначені кандидати після проведення відповідних навчань були залучені для проведення тренінгів по підвищенню рівня знань співробітників правоохоронних органів України. Протягом липня 2019 році в рамках Проекту 57 на базі Наукового центру відбулися командно-штабний тренінг (5 липня) і національні навчання (22-25 липня).

У командно-штабному тренінгу взяли участь експерти правоохоронних органів України і Молдови. Виконання вправ проводилося в групах, а результати роботи демонструвалися і обговорювалися в режимі скайп-конференції.

Національні навчання проведено у форматі практичних вправ на спеціально підготовленій території Наукового центру. Учасники тренінгу працювали з імітаційними речовими доказами в захисних костюмах з використанням технічних засобів у реальних ситуаціях у реальному часі.

Окрім набуття практичних навичок, відбувся обмін знаннями та досвідом між різними відомствами - суб'єктами взаємодії в умовах хімічної загрози. Учасники здобули досвід, що сприятиме підвищенню рівня управлінських навичок і покращенню координації та комунікаиії між суб'єктами взаємодії, що беруть участь у реагуванні на РХБЯ інциденти.

Висновки. Проведені навчання довели необхідність впровадження системи постійної професійної підготовки і підвищення кваліфікації співробітників спеціальних і силових структур України, що залучаються до розслідування РХБЯ інцидентів. Ключові слова: хімічна, біологічна, радіаційна та ядерна безпека, безперервний професійний розвиток. 


\section{СОВРЕМЕННАЯ МОДЕЛЬ УЧЕБНО-ТРЕНИНГОВОГО ЦЕНТРА \\ ПО ПОДГОТОВКЕ ЭКСПЕРТОВ В ОБЛАСТИ ХИМИЧЕСКОЙ, БИОЛОГИЧЕСКОЙ, РАДИАЦИОННОЙ И ЯДЕРНОЙ БЕЗОПАСНОСТИ}

(Результаты первого тренинга по химической безопасности в рамках Проекта 57:

Усиление существующих экспертно-криминалистических возможностей при расследовании ХБРЯ инциентов. Украина, Киев, июль 2019)

С.П. Бережнов ${ }^{1}$, А.И. Петрашенко ${ }^{1}$ Н.В. Курдиль ${ }^{1}$, М.Л. Зиновьева ${ }^{1}$, Д.В. Федь ${ }^{2}$, В.А. Ракс ${ }^{3}$,

Н.Г. Завьялова ${ }^{4}$, Л.А. Устинова ${ }^{5}$, В.П. Коробка ${ }^{6}$, Р.М. Швеи 6

${ }^{1}$ ГП «Научный центр превентивной токсикологии, пищевой и химической безопасности имени академика Л.И. Медведя Министерства здравоохранения Украины», г. Киев, Украина

${ }^{2}$ Международный исследовательский центр предотвращения последствий ХБРЯ угроз, г. Киев, Украина

${ }^{3}$ Киевский национальный университет имени Тараса Шевченко, кафедра аналитической химии, г. Киев, Украина

${ }^{4}$ Государственный научно-исследовательский экспертно-криминалистический центр МВД Украины, г. Киев, Украина

${ }^{5}$ Украинская военно-медицинская академия, кафедра военной токсикологии, радиологии и медицинской защиты, Украина, Киев

бЧП «Спаринг-Вист Центр», г. Киев, Украина

РЕЗЮМЕ. Минимизация последствий, связанных с химической, биологической, радиационной и ядерной (РХБЯ) опасностью, требует одновременных усилий различных специалистов не только в пределах одного государства, поэтому в последнее время международные проекты стремятся разрабатывать и внедрять не только национальные меры по минимизации РХБЯ угроз, но и координировать действия на международном уровне.

Цель. Обоснование актуальности организации постоянно действующего международного тренинг-центра по подготовке специалистов в сфере РХБЯ безопасности (направление - химическая безопасность) для силовых и специальных структур Украины.

Материалы и методы. Результаты проведенных учений и тренингов в рамках проекта, посвященного созданию сети тренинг-центров по минимизаци рисков, связанных с РХБЯ угрозами в странах региона Юго-Восточной и Восточной Европы, которые прошли на базе ГП «Научный центр превентивной токсикологии, пищевой и химической безопасности имени академика Л.И. Медведя МОЗ Украины»(Научный центр) в июле 2019.

Результаты и обсуждение. Проект 57 - «Усиление существующих экспертно-криминалистических возможностей при расследовании РХБЯ инцидентов» (англ. Project 57: Strengthening crime scene forensics capabilities in investigating CBRN incidents in the South East and Eastern Europe Centers of Excellence Region (Ref: Europe Aid/IFS/2016/374993) начал деятельность в 2019 году. Задача проекта 57 - внедрение системы тренингов по расследованию РХБЯ иниидентов и постепенное формирование взаимосвязей между экспертами-криминалистами и организациями, имеющими опыт работы в сфере РХБЯ материалов на национальном уровне. В рамках реализации проекта 57 от Украины были привлечены украинские эксперты, прошедшие обучение и подготовку в странах ЕС в качестве национальных инструкторов судебно-криминалистической экспертизы на месте преступления при расследовании инцидентов, связанных с РХБЯ материалами. Указанные кандидаты после проведения соответствующих учений были привлечены для проведения тренингов по повышению уровня знаний сотрудников правоохранительных органов Украины. В течение июля 2019 года в рамках проекта 57 на базе Научного иентра состоялись командно-штабной тренинг (5 июля) и национальные учения (22-25 июля).

В командно-штабном тренинге принимали участие эксперты правоохранительных органов Украины и Молдовы. Выполнение упражнений проводилось в группах, а результаты работы демонстрировались и обсуждались в режиме скайпконференции. Национальные учения были проведены в формате практических упражнений на специально подготовленной территории Научного центра. Участники тренинга работали с имитационными вещественными доказательствами в защитных костюмах с использованием технических средств в реальных ситуациях в реальном времени.

Кроме приобретения практических навыков, состоялся обмен знаниями и опытом между различными ведомствами - суббектами взаимодействия в условиях химической угрозы. Участники приобрели опыт, который будет способствовать повышению уровня управленческих навыков и улучшению координации и коммуникаций между субъектами взаимодействия при реагировании на РХБЯ инциденты.

Выводы. Выполнение задач по расследованию РХБЯ инцидентов требует постоянного профессионального совершенствования специалистов различных отраслей и развития системы коммуникации и взаимодействия на междисциплинарном уровне. Проведенные учения подтвердили необходимость внедрения системы постоянной профессиональной подготовки и повышения квалификации сотрудников специальных и силовых структур Украины, привлекаемых для расследования РХБЯ инцидентов.

Ключевые слова: химическая, биологическая, радиационная и ядерная безопасность, непрерывное профессиональное развитие.

Received 06/09/2020 